\title{
Genetic diversity in apple tree cultivars established in the Sierra de Arteaga, Coahuila, Mexico
}

\section{Diversidad genética en cultivares de manzano establecidos en la Sierra de Arteaga Coahuila, México}

\author{
Mayra Alejandra Escobar-Saucedo ${ }^{1}$, Cristóbal Aguilar ${ }^{1}$, Antonio Vázquez-Ramos ${ }^{2}$, Manuel Humberto \\ Reyes-Valdés ${ }^{3}$, Raúl Rodríguez-Herrera ${ }^{1 *}$. \\ ${ }^{1}$ Departamento de Investigación en Alimentos. Facultad de Ciencias Químicas, Universidad Autónoma de Coahuila. Blvd. \\ Venustiano Carranza s/n, Col. República Oriente. CP. 25280, Saltillo, Coahuila, México. \\ ${ }^{2}$ Campo Experimental Saltillo, INIFAP. Carretera Saltillo - Zacatecas km. 342+119, Número 9515, Hacienda de Buenavista, \\ CP. 25315, Saltillo, Coahuila, México. \\ ${ }^{3}$ Departamento de Fitomejoramiento. Universidad Autónoma Agraria Antonio Narro. Calzada Antonio Narro 1923, Buenavista, \\ CP. 25315, Saltillo, Coahuila, México. \\ *Corresponding author: raul.rodriguez@uadec.edu.mx
}

Scientific note received: November 15, 2016 accepted: June 6, 2017

\begin{abstract}
Apple production in the Sierra de Arteaga, Coahuila is mainly based on the Golden Delicious cultivar. Production based on only a few cultivars represents a genetic risk, because if they are susceptible to a pest, disease or climate change much of this production would be lost if one or more of these conditions occurred. Foreseeing this situation, farmers have introduced different commercial apple cultivars, but there is little information about the genetic diversity among them. Therefore, the aim of this study was to estimate the rates of intraspecific genetic diversity of 12 different apple cultivars using inter-simple sequence repeat (ISSR) molecular markers. Employing nine ISSR primers, it was possible to identify 124 DNA bands, of which $63 \%$ were polymorphic, with genetic diversity of 0.24 . Results suggest that these cultivars are adapted to the region's climate and can be utilized to increase the overall plantation area, in order not to depend on a single cultivar.
\end{abstract}

Key words: Genetic diversity, chilling units, Malus domestica Borkh, ISSR, polymorphism

RESUMEN. La producción de manzana en la Sierra de Arteaga, Coahuila se basa principalmente en el cultivar Golden Delicious. La siembra de pocos cultivares representa un riesgo, de plagas, enfermedades o cambios climáticos, que pueden afectar la producción. Por lo que los agricultores han introducido diferentes variedades de manzano, de los que no se tiene información sobre su diversidad genética. El objetivo fue estimar los índices de diversidad genética intraespecíficos con marcadores moleculares intersecuencias simples repetidos (ISSR) de 12 cultivares de manzano de la Sierra de Arteaga. Con ayuda de nueve iniciadores se identificaron 124 bandas, de las cuales el $63 \%$ fueron polimórficas, con diversidad genética de 0.24. Los resultados sugieren que éstos cultivares están adaptados a las condiciones climáticas de la región y se pueden utilizar para incrementar el área de plantación, para no depender de un cultivar.

Palabras clave: Diversidad genética, horas frío, Malus domestica Borkh, ISSR, polimorfismo

\section{INTRODUCTION}

The apple tree (Malus domestica Borkh) is an important temperate-climate fruit tree in Mexico, with its 2015 production totaling $750324.85 \mathrm{t}$. It is grown mainly in the states of Chihuahua, Durango,
Puebla and Coahuila; in the last state, the main production is in the Sierra de Arteaga, with an annual production of $26211.18 \mathrm{t}$ of apple in 5770 ha (SIAP 2016), in which the Red Delicious and Golden Delicious cultivars are planted (Contreras de la Reé et al. 2010). Agricultural production based on a few culti- 




vars is subject to risks, because genetic uniformity is vulnerable to pests, diseases or environmental stress (Granados et al. 2009), as occurred with the devastation of the potato crop by Phytophthora infestans in Ireland (Woodham- Smith 1991), or in the case of the current problem facing U.S. apple (Malus) production due to the low number of varieties cultivated (Gayle et al. 2015). One way to avoid problems due to pests or diseases is to maintain genetic diversity in the crops, through the conservation of different cultivars (Granado et al. 2009). The greater the genetic diversity in a breeding program, the better the chances of developing new cultivars with resistance to diseases, quality and productivity (Smolik and Krzysztoszek 2010).

The effectiveness of breeding programs depends on the nature and magnitude of the variability (Lado et al. 2012), and on the use of molecular genetic markers, which allow specifying and quantifying the phylogenetic relationships between closely related species (Savelyeva and Kudryavtse 2015). Within the genetic markers are the DNA markers, such as the Inter-Simple Sequence Repeats (ISSR), which besides being highly polymorphic allow obtaining a variation in DNA regions between the microsatellites that are dispersed throughout the genome (Rizkalla et al. 2012). ISSRs have been used to identify genotypes in crops such as pear (Kalkisim et al. 2016), mango (Singh et al. 2007), mulberry (Prasanta et al. 2008), papaya (Carrasco et al. 2009) cucumber and melon (Parvathaneni et al. 2011), wheat (Rizkalla et al. 2012), and birch (Pan et al. 2006), among others. These markers have been shown to have an advantage for apple diversity studies (Smolik and Krzysztoszek 2010, $\mathrm{He}$ et al. 2011). Based on the above and in view of the little genetic information available about the apple cultivars established in the Sierra de Arteaga, Coahuila, the objective of this study was to determine the genetic diversity of 12 apple cultivars adapted to the climatic conditions of the Sierra de Arteaga, Coahuila through microsatellites (ISSR).
Genetic diversity of apple trees in Coahuila

Ecosist. Recur. Agropec. 5(13):65-70,2018

\section{MATERIALS AND METHODS}

\section{Plant material}

Leaves were collected from 12 apple cultivars whose chilling requirements vary between 400 and 600 chilling units (CU). The cultivars were: Corail, Imperial Gala, Honey Crisp, Gale Gala, Glory, Buckeye Gala, Cameo, Pink Lady, Española, Royal Gala and Pacific Gala. The cultivar Golden Delicious was used as a control; it has requirements between 900 and $1200 \mathrm{CU}$. Plant tissue sampling was carried out in the town of San Antonio de las Alazanas, Municipality of Arteaga, Coahuila.

\section{DNA Extraction}

The extraction of DNA was done from healthy leaves of each cultivar, with the modified CTAB technique. From each leaf, $0.1 \mathrm{~g}$ was taken and ground with liquid nitrogen. $1 \mathrm{X}$ CTAB lysis solution [5 M NaCl, 0.5 M EDTA ( $\mathrm{pH} 8), 1 \mathrm{M}$ Tris 1 $\mathrm{M}(\mathrm{pH} 8)$ and $0.5 \%$ 2-mercaptoethanol] was used. The obtained material was washed with chloroformisoamyl alcohol $(24: 1 \mathrm{~V} / \mathrm{V})$ and the supernatants were washed with $99 \%$ ethanol, after which they were left for $60 \mathrm{~min}$ at $-20^{\circ} \mathrm{C}$. After this, the sample was centrifuged at $13300 \mathrm{~g}$ for $15 \mathrm{~min}$ and the supernatant was discarded, the formed pellet was washed three times with $70 \%$ ethanol, left to dry at room temperature and stored in $50 \mu \mathrm{L}$ of TE (1X) plus $10 \mu \mathrm{L}$ of RNase prepared at a concentration of $1 \mu \mathrm{g} \mu \mathrm{L}^{-1}$. DNA integrity was tested on a $1 \%$ agarose gel and quantification was performed with the Gen5 1.11 DNA program.

\section{ISSR Analysis}

Nine primers (Table 1) were tested at different temperatures in standard condition and then amplification conditions were optimized by gradient PCR, in order to obtain clear bands. Amplification was performed with polymerase chain reaction (PCR) in a volume of $11.5 \mu \mathrm{L}$, composed of $3.0 \mu \mathrm{L}$ of $\mathrm{ddH}_{2} \mathrm{O}, 2.17 \mathrm{X}$ of $10 \mathrm{X}$ buffer solution added with $\mathrm{MgCl}_{2}, 0.21 \mathrm{mM}$ of the dNTP's mixture, $2.6 \mu \mathrm{M}$ of each primer, $8.7 \%$ of DMSO, $0.1 \mathrm{U}$ of PaqDNA 
Table 1. ISSR primers used for PCR amplification of apple tree samples, number of products amplified per primer and level of polymorphism obtained.

\begin{tabular}{clccc}
\hline Primer & Sequence $\left(5^{\prime}-3^{\prime}\right)$ & Annealing temperature $\left({ }^{\circ} \mathrm{C}\right)$ & Total No. of bands & Polymorphic bands $(\%)$ \\
\hline 1 & GAGAGAGAGAGAGAGATC & 47.7 & 15 & 86.67 \\
2 & AGAGAGAGAGAGAGAGTC & 49.7 & 11 & 72.73 \\
3 & CTCTCTCTCTCTCTCTAG & 40 & 12 & 50.00 \\
4 & CTCCTCCTCCTCCTCCTC & 55 & 13 & 38.46 \\
5 & GAGAGAGAGAGAGAGAT & 52 & 15 & 53.33 \\
6 & GTGTGTGTGTGTGTGTA & 48 & 15 & 60.00 \\
7 & AGCAGCAGCAGCAGCGA & 49 & 14 & 50.00 \\
8 & GTGTGTGTGTGGTGTTC & 47 & 14 & 42.86 \\
9 & TCTCTCTCTCTCTCTCC & 54.6 & 15 & 60.00 \\
\hline
\end{tabular}

polymerase at a concentration of $5 \mathrm{U} \mu \mathrm{L}^{-1}$ and DNA. In a Px2 Thermal Cycler, PCR was performed with an initial denaturation temperature of 1 min at $94{ }^{\circ} \mathrm{C}, 40$ cycles composed of denaturation of $1 \mathrm{~min}$ at $94{ }^{\circ} \mathrm{C}$, annealing of $45 \mathrm{~s}$ and extension of $2 \mathrm{~min}$ at $72{ }^{\circ} \mathrm{C}$, followed by an extension step of $7 \mathrm{~min}$ at $72{ }^{\circ} \mathrm{C}$. The amplification products were visualized on $1.5 \%$ agarose gels with SB $1 \mathrm{X}$ buffer and stained with ethidium bromide. With an Axygen Biosciences $100 \mathrm{bp}$ marker, the size of each of the fragments obtained was determined.

\section{Statistical Analysis}

Each band obtained in the agarose gels was considered as a locus and codified as absence (zero) and presence (one) for each cultivar studied. All analyses were performed with the InfoGen v. 2011 program (Di Rienzo et al. 2008) to calculate the percentage of polymorphic ISSR, genetic diversity, Nei's unbiased heterozygosity and effective number of alleles. In order to cluster the different genotypes evaluated, a dendrogram was created using Sokal Sneath distance 3 , since it was the one with the highest cophenetic correlation (0.888).

\section{RESULTS AND DISCUSSION}

The molecular characterization of the 12 apple samples was carried out with the ISSR technique. The advantage of this molecular tool lies in its great capacity to detect differences between individuals that may be related (Azofeifa-Delgado 2006). Using nine ISSR primers, we amplified a total of 124 bands, of which $63.71 \%$ had polymorphism.
An example of the DNA polymorphism patterns generated by the first primer [(GA) 8T] is shown in Figure 1. Results indicate a diversity of 0.24 and average number of alleles of 1.637 , indicating genetic variability. Some authors point out that ISSR markers allow finding high levels of polymorphism between individuals and are widely used for the identification of cultivars of the Malus species. In this regard, Calvo et al. (2014) determined the genetic variability of 23 populations of wild apple trees in the Andean mountain range, finding a total of 46 alleles with 10 SSR primers and a genetic variation of $66 \%$ among the populations. In the same vein, $\mathrm{He}$ et al. (2011) evaluated wild apple trees with 20 ISSR primers and report 110 polymorphic bands and a similarity coefficient of 0.74 to 0.94 among cultivars. On the other hand, Smolik and Krzysztoszek (2010) evaluated the genetic variability of eight apple tree cultivars, among which Golden Delicious stands out, confirming the great advantage that the ISSR have against other traditional methods of characterization and estimation of diversity, since this type of molecular marker is not affected by environmental conditions.

The number of cultivars evaluated in the present study is small, but with the bands found, a dendrogram (Figure 2) was obtained that shows the formation of two groups. Group one is formed by the cultivars Gale gala, Royal gala and Pacific gala, with chilling requirements that oscillate around 400 CU. In addition, these three cultivars present similar banding patterns and extra bands at $250 \mathrm{bp}$ with the primers six, eight and nine; this same group includes the Golden Delicious control sample, which 




Figure 1. DNA amplification patterns generated by the primer $(\mathrm{GA})_{8} \mathrm{~T}$ in the samples, lane $\mathrm{M}=$ molecular marker, $1=$ Corail, 2=Imperial Gala, 3=Honey Crisp, 4=Gale Gala, 5=Glory, $6=$ Buckeye Gala, 7=Cameo, 8=Pink lady, 9=Española, 10=Royal Gala, 11=Pacific Gala, $12=$ Golden Delicious.

despite requiring between 900 and $1200 \mathrm{CU}$ to leave dormancy and start to flower (Contreras de la Reé et al. 2010) shares band similarity with Royal gala in most of the patterns generated with the primers evaluated.

Group two includes eight cultivars, the Spanish cultivar being the most different. Within this group are the cultivars Buckeye gala and Imperial gala, which require between 450 and $500 \mathrm{CU}$ to flower; in addition, the fruit that these two cultivars produce is redder and its color is established up to 10 $\mathrm{d}$ before Pacific gala and Royal gala, while Buckeye gala is one of the first cultivars to be harvested (Contreras de la Reé et al. 2010). The two cultivars that showed a high level of similarity between them were Honey crisp and Buckeye gala, with a distance of 0.49 , despite presenting different chilling requirements. These two cultivars have the same banding pattern with primers three and four, in addition to minimal banding differences with the other seven primers between 100 and $400 \mathrm{bp}$. These two cul- tivars are joined by Cameo, which is the only one that presents a band at 500 bp with primer number eight and at $550 \mathrm{bp}$ with primer number 6 .

Results indicate a good molecular characterization in the cultivars evaluated, but the genetic diversity found does not correlate with the fruit quality, chilling requirement or flowering time that the cultivars present. The level of polymorphism found among them suggests proposing the establishment of plantations with a greater diversity of cultivars, adapted to the climatic conditions of the region, so as not to depend on only a few cultivars for apple production in the Sierra de Arteaga, Coahuila.

\section{ACKNOWLEDGEMENTS}

The authors are grateful to SNI-CONACYT for funding the project "Genotyping and bromatological characterization of three apple mutants" and to the Government of the State 


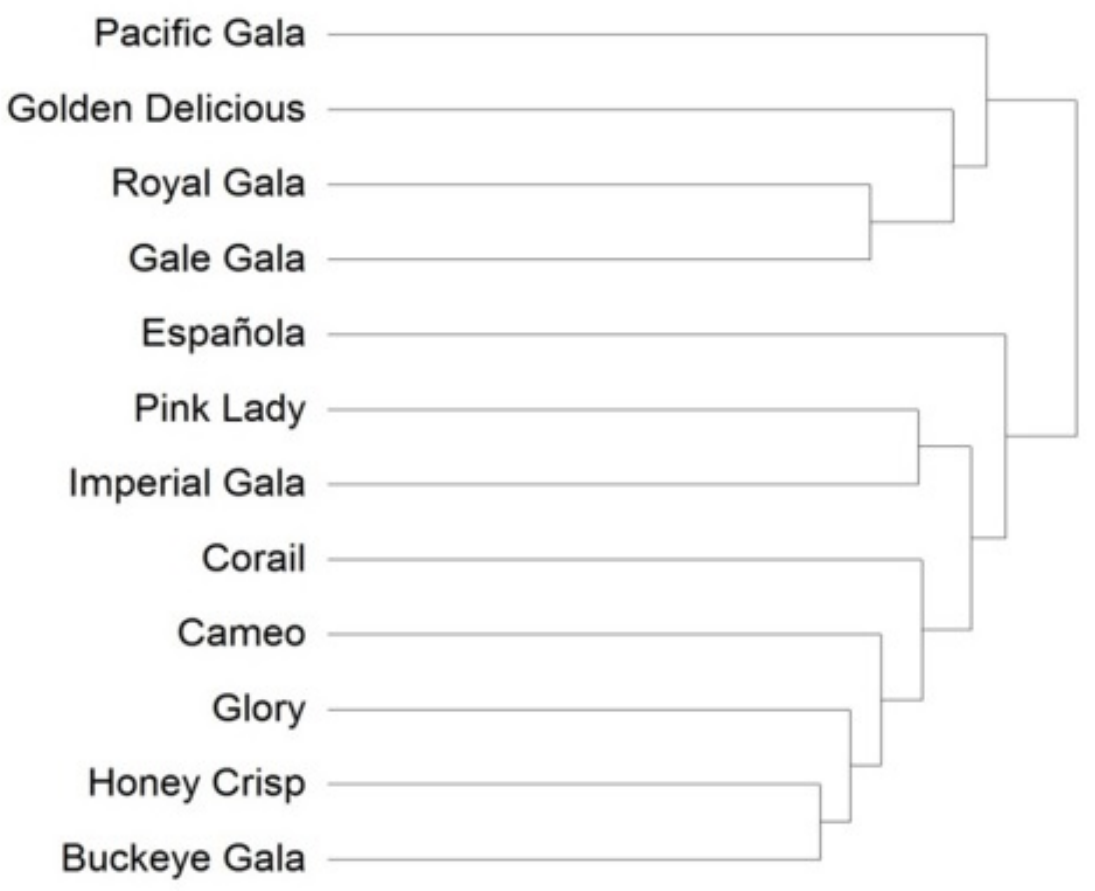

$0,00 \quad 0,20 \quad 0,39 \quad 0,59 \quad 0,78$

Figure 2. Clustering of 12 commercial apple tree cultivars, grown in the Arteaga region, Coahuila, based on ISSR markers with the Sokal Sneath 3 distance matrix.

of Coahuila-FONCYT-COECYT-CONACYT-20132014 for founding for the project "Bromatological characterization, genetics/epigenetics of apple mu- tants for low chilling requirements". MAES thanks CONACYT for the financial support received for the completion of her postgraduate studies.

\section{LITERATURE CITED}

Azofeifa-Delgado A (2006) Uso de marcadores moleculares en plantas: Aplicaciones en frutales del trópico. Agrnomía Mesoamericana 17: 221-242.

Calvo P, Carrera A, Poverene MM (2014) Genética de poblaciones y evolución. Variabilidad genética en poblaciones argentinas de manzano silvestre (malus sp.) con marcadores SSR. Journal of Basic and Applied Genetics 25: 227-251.

Carrasco B, Avila P, Pérez-Días J, Muñoz P, García R, Lavandero B, et al. (2009) Genetic structure of highland papayas (Vasconcellea pubescens (Lenné et C. Koch) Badillo) cultivated along a geographic gradient in Chile as revealed by Inter Simple Sequence Repeats (ISSR). Genetic Resources and Crop Evolution 56: 331-337.

Contreras de la Reé FJ, Vázquez Ramos JA (2010) Cultivares y mutantes de manzana para el sureste de Coahuila. Folleto para productores. Número14. INIFAP. Campo Experimental Saltillo. México 16p.

Di Rienzo JA, Casanoves F, Balzarini MG, Gonzalez L, Tablada M, Robledo CW (2008) InfoStat, versión 2008, Grupo InfoStat. Universidad Nacional de Córdoba. Argentina. 336p. 
Gayle MV, Chao CT, Norelli J, Brown SK, Fazio G, Peace C, McFerson J, Zhong GY, Bretting P (2015) The vulnerability of US apple (Malus) genetic resources. Genetic Resources and Crop Evolution 62: 765-794.

Granados SGF, López Ríos MA, Hernández GMA (2009) Recursos genéticos, biotecnología y propiedad intelectual. Revista Chapingo Serie Ciencias Forestales y del Ambiente 15: 127-140.

He P, Li L, Li H, Wang H, Yang J, Wang Y (2011) Genetic analysis of wild apple resources in Shandong province based on inter-simple sequence repeats (ISSR) and sequence-specific amplification polymorphism (S-SAP) markers. African Journal of Biotechnology 10: 9501-9508.

Kalkisim O, Okeu M, Okcu Z, Karabulut B, Yildirim N, Agar G (2016) Relationships among some pears genotypes (Pyrus Communis L.) based on ISSR and RAPD analysis. Erwerbs-Obstbau 58: 259-264.

Lado B, Poland J, Belzile F, Del Pozo A, Matus I, Rodríguez A, et al. (2012) Genotipado por secuenciación del genoma de 384 genotipos de T. aestivum para selección genomica. Journal of Basic \& Applied Genetics 23: 267.

Pan H, Yang CH, Wei Z, Jiang J (2006) DNA extraction of birch leaves by improved CTAB method and optimization of its ISSR system. Journal of Forestry Research 4: 298-300.

Parvathaneni RK, Natesan S, Devaraj AA, Muthuraja R, Venkatachalam R, Subramani AP, et al. (2011) Fingerprinting in cucumber and melon (Cucumis spp.) genotypes using morphological and ISSR markers. Journal of Crop Science and Biotechnology 1: 39-43.

Prasanta KK, Srivastava PP, Awasthi AK, Urs SR (2008) Genetic variability and association of ISSR markers with some biochemical traits in mulberry (Morus spp.) genetic resources available in India. Tree Genetics And Genomes 4: 75-83.

Ríasco JJ, Victoria JI, Angel F (2003) Diversidad genética en variedades de caña de azúcar (Saccharum spp.) usando marcadores moleculares. Revista Colombiana de Biotecnología 1: 6-15

Rizkalla SA, Attia A, El-Hady A, Hanna NS, Nasseef JE (2012) Genetic diversity based on ISSR and protein markers associated with earliness trait in wheat. World Applied Sciences Journal 20: 23-33.

Savelyeva EN, Kudryavtsev AM (2015) AFLP analysis of genetic diversity in the genus Mallus Mill. (Apple). Russian Journal of Genetics 10: 1126-1133.

SIAP (2016) Servicio de Información Agroalimentaria y Pesquera. Producción anual de manzano. Cierre de la producción aagrícola de manzana por estado para el año 2014, modalidad riego más temporal. http://infosiap.siap.gob.mx/aagricola_siap_gb/ientidad/index.jsp. Date consulted: March 13, 2017.

Singh S, Karihalloo JL, Gaikwad AB (2007) DNA fingerprinting of some mango (Mangifera indica L) cultivars using anchored-ISSR markers. Journal Plant Biochemisty and Biotechnology 2: 113-117.

Smolik M, Krzysztoszek O (2010) Evaluation of genetic variability in chosen apple (Malus $\times$ domestica Borkh.) cultivars by ISSR-PCR analysis. Russian Journal of Genetics 46: 923-931.

Woodham-Smith C (1991) The great hunger: Ireland 1845-1849. $2^{\text {nd }}$ edition. Penguin Books. London England. 521p. 